\title{
PENYELESAIAN HUKUM KEKERASAN DALAM RUMAH TANGGA SECARA NONLITIGASI DI DESA TANJUNG SETEKO KECAMATAN INDRALAYA KABUPATEN OGAN ILIR PROVINSI SUMATERA SELATAN
}

\author{
Meria Utama, Muhammad Syahri Ramadhan, Yunial Laili Mutiari, Usmawadi, Reza Putra Juanda, Larissa Levina, \\ Muhammad Rezky Bagus Rekso \\ Jurusan Ilmu Hukum, Fakultas Hukum, Universitas Sriwijaya \\ Email: msyahriramadhan@fh.unsri.ac.id
}

\begin{abstract}
Domestic violence happened more experienced by a woman right here is located as a wife or children who were victims, while it was dominated by mans located as a husband or son. Domestic violence can be caused by various factors, both internal and external factors in the household .Internal factors can lead to domestic violence among others , violent offenders character to emotion, economic dependence, a third party in the household, the state of the economy, and communication that went well .Change in the mindset especially of women in society had been changed, it was proven by the increasing a divorce in court .Changes this thinking actually form a view that marriage are not sacred and do not have to fight for comprehensive when they have found a difference. Whereas the problems domestic violence can be done by means of nonlitigation/ outside the court .Extension activities law the completion of domestic violence law by husband from their outside the court in the district of Tanjung Seteko, Ogan ilir is expected to make to the public about the act of actions which includes domestic violence and the negative. In addition it is hoped covered by it is hoped people understand that domestic violence can finished first through the non-litigation or outside the court .
\end{abstract}

Keywords - Domestic violence, tanjung seteko village, nonlitigation. Abstrak - Kekerasan yang terjadi dalam rumah tangga
lebih banyak dialami perempuan yang di sini
berkedudukan sebagai seorang istri atau anak yang
menjadi korban, sedangkan pelakunya didominasi
oleh laki-laki yang berkedudukan sebagai seorang
suami atau anak. Kekerasan dalam rumah tangga dapat
disebabkan oleh berbagai faktor, baik faktor internal
maupun eksternal dalam lingkup rumah tangga. Faktor
internal yang dapat memicu terjadinya kekerasan
dalam rumah tangga antara lain, karakter pelaku
kekerasan yang cenderung emosi, ketergantungan
ekonomi, pihak ketiga dalam rumah tangga, keadaan
ekonomi, dan komunikasi yang berjalan dengan tidak
baik. Perubahan pola pikir dalam masyarakat
khususnya perempuan saat ini sudah berubah, hal ini
terbukti dengan semakin meningkatnya gugatan
perceraian di Pengadilan. Perubahan pemikiran ini
seakan-akan membentuk suatu pandangan bahwa
perkawinan bukanlah hal yang sakral sehingga tidak
perlu diperjuangkan keutuhannya jika telah ditemukan
perbedaan. Padahal permasalahan kekerasan dalam
rumah tangga ini dapat dilakukan dengan cara di luar pengadilan (nonlitigasi). Kegiatan Penyuluhan Hukum Penyelesaian Hukum Kekerasan Dalam Rumah Tangga Yang Dilakukan Suami Terhadap Istri Di Luar Pengadilan Di Desa Tanjung Seteko Kecamatan Indralaya Kabupaten Ogan Ilir Provinsi Sumatera Selatan ini diharapkan dapat memberikan pemahaman kepada masyarakat tentang tindakan - tindakan yang termasuk KDRT dan efek negatifnya. Selain itu diharapkan dengan adanya penyuluhan tersebut diharapkan masyarakat memahami bahwa Kekerasan Dalam Rumah Tangga (KDRT) dapat diseleseaikan terlebih dahulu melalui jalur non-litigasi atau di luar pengadilan.

Kata Kunci - Kekerasan Dalam Rumah Tangga (KDRT), Desa Tanjung Seteko, Nonlitigasi

\section{PENDAHULUAN}

Kekerasan Dalam Rumah Tangga (selanjutnya disingkat KDRT) merupakan tindakan yang dilakukan di dalam rumah tangga baik oleh suami, istri, maupun anak yang berdampak buruk terhadap keutuhan fisik, psikis, dan keharmonisan hubungan sesuai yang diatur dalam pasal 1 UU Nomor 23 tahun 2004 tentang Penghapusan Kekerasan dalam Rumah Tangga (selanjutnya disingkat UU PKDRT).[1] Ruang lingkup dari tindakan KDRT ini sendiri terdiri dari suatu tindakan kepada seseorang terutama wanita, yang dimana perbuatan tersebut dalam memberikan efek negatif berupa kesengsaraan atau penderitaan secara fisik, seksual, psikologis, dan/atau penelantaran rumah tangga termasuk ancaman untuk melakukan perbuatan, pemaksaan, atau perampasan kemerdekaan secara melawan hukum dalam lingkup rumah tangga [2].

Mayoritas kalangan yang sering menjadi korban KDRT adalah kaum perempuan (istri) dan pelakunya ialah suami, meskipun ada juga beberapa kasus yang menjadi korban justru sebaliknya, atau orangorang yang tersubordinasi di dalam lingkup rumah tangga tersebut. Pihak perempuan atau 
istri seringkali menjadi korban dikarenakan masih banyak mengorientasikan dalam perspektif gender, bahwa perempuan adalah kaum yang lemah dan dalam konteks rumah tangga, perempuan selaku istri harus berada dalam kendali pihak laki - laki atau suami. Adanya disorientasi pemahaman seperti inilah yang menyebabkan kasus KDRT masih sering terjadi [2]. Pelaku atau korban KDRT adalah orang yang mempunyai hubungan darah, perkawinan, persusuan, pengasuhan, perwalian dengan suami, dan anak bahkan pembantu rumah tangga yang tinggal dalam sebuah rumah tangga.[3] Tidak semua tindakan KDRT dapat ditangani secara tuntas karena korban sering menutupnutupi dengan alasan ikatan struktur budaya, agama, dan belum dipahaminya sistem hukum yang berlaku. Padahal perlindungan oleh negara dan masyarakat bertujuan untuk memberi rasa aman terhadap korban serta menindak pelakunya [4]. KDRT selalu diindentikan dengan kekerasan fisik saja, padahal terdapat macam bentuk kekerasan yang tidak hanya berkaitan dengan hal fisik saja. Hal ini sebagaimana diatur dalam Pasal 5 UU PKDRT yang menyebutkan "setiap orang dilarang melakukan kekerasan dalam rumah tangga terhadap orang dalam lingkup rumah tangganya, dengan cara: a. Kekerasan fisik; b. Kekerasan psikis; c. Kekerasan seksual; d. Penelantaran rumah tangga" [5].

Bentuk kekerasan yang sering terjadi ialah kekerasan fisik dan psikis. Bentuk kekerasan fisik ini misalnya seperti memukul, menendang, dan menjambak. Kekerasan psikis ini sendiri biasanya dilakukan melalui serangan verbal yang dapat merendahkan harga diri korban, memberikan rasa takut bahkan depresi bagi pihak korban [6]. Kekerasan fisik dalam KDRT biasanya diawali dengan adanya kekerasan psikis atau serangan verbal dari pelaku. Hal ini dikarenakan pihak korban memberikan ruang bagi pelaku untuk menyerang dirinya melalui serangan verbal sehingga kondisi psikisnya terganggu, akibatnya pelaku semakin leluasa untuk melakukan bentuk kekerasan lainnya yaitu kekerasan fisik [7].

Kalangan perempuan baik bagi yang berkedudukan sebagai istri maupun anak seringkali menjadi korban, sedangkan para pelaku dalam KDRT biasanya didominasi oleh kalangan laki - laki baik yang berkedudukan sebagai suami bahkan anak. Berdasarkan fenomena tersebut, tidak mengherankan jika di dalam UU PKDRT lebih memfokuskan pemberian perlindungan hukum terhadap kaum perempuan. Ada 2 (dua) faktor yang menyebabkan KDRT dapat terjadi di dalam sebuah rumah tangga, adapun kedua faktor tersebut ialah faktor eksternal dan faktor internal. Faktor internal yang dapat memicu terjadinya kekerasan dalam rumah tangga antara lain, karakter pelaku kekerasan yang cenderung emosi, ketergantungan ekonomi, pihak ketiga dalam rumah tangga, keadaan ekonomi, dan komunikasi yang berjalan dengan tidak baik. Sementara faktor eksternal yang dapat memicu terjadinya kekerasan dalam rumah tangga antara lain, perbedaan budaya/kebiasaan seperti bila suami berasal dari suku tertentu yang terkenal keras, sedangkan si istri berasal dari suku tertentu yang bersifat lemah lembut, mereka walaupun sudah menjadi suami-istri yang harusnya saling memahami dan saling menerima satu sama lain, justru itu tidak terjadi, yang akhirnya terjadilah egoisme masing-masing dan memaksakan kehendaknya sehingga munculah tindak kekerasan di dalam keluarga tersebut yang memandang perempuan sebelah mata dan faktor seperti kesalahan penafsiran ajaran agama didalam masyarakat, seperti perbedaan agama/keyakinan [8].

Semakin bertambahnya jumlah kasus gugatan perceraian di Pengadilan terutama di pengadilan agama, mengindikasikan pola pikir perkembangan kaum perempuan terutama bagi si istri sudah mulai berubah [9]. Semenjak adanya UU PKDRT, yang lebih memfokuskan kepada perlindungan hukum terhadap perempuan, membuat kalangan perempuan semakin meningkat rasa percaya dirinya dalam menanggapi persoalan KDRT tersebut. Jika rasa percaya diri terhadap eksistensi perlindungan hukum bagi kaum perempuan terhadap KDRT terlalu berlebihan, maka hal tersebut juga bukan merupakan hal yang baik. KDRT apabila terlalu dini dengan disikapi dengan adanya perceraian, maka hal tersebut dapat memicu paradigma baru yaitu perkawinan bukanlah hal yang sakral sehingga tidak perlu diperjuangkan keutuhannya jika telah ditemukan perbedaan atau dipenuhi konflik rumah tangga. Sepatutnya segala permasalahan rumah tangga termasuk KDRT diupayakan terlebih dahulu dengan cara di luar pengadilan (nonlitigasi) [9]. Hal inilah kemudian yang melatarbelakangi tim pengabdian Fakultas Hukum Universitas Sriwijaya melaksanakan kegiatan penyuluhan hukum tentang 
Penyelesaian Hukum Kekerasan Dalam Rumah Tangga Yang Dilakukan Suami Terhadap Istri Secara Nonlitigasi Di Desa Tanjung Seteko Kecamatan Indralaya Kabupaten Ogan Ilir.

\section{METODE PENGABDIAN}

Khalayak sasaran dalam kegiatan pengabdian ini ialah Masyarakat di Wilayah Desa Tanjung Seteko, Kecamatan Indralaya, Kabupaten Ogan Ilir, Provinsi Sumatera Selatan. Pihak tim pengabdian FH Unsri selalu melakukan koordinasi dan proses administratif dengan Kepala Desa Tanjung Seteko, Kecamatan Indralaya, Kabupaten Ogan Ilir, Provinsi Sumatera Selatan, demi untuk dapat diizinkan melakukan Penyuluhan Hukum di lokasi tersebut. Adapun kegiatan pengabdian tersebut diadakan pada : Hari/Tanggal Sabtu, 11 September 2021, Pukul 09.00 WIB sampai dengan Pukul 12.00 WIB, yang dimana peserta kegiatan ialah Kepala desa, aparat desa, kepala dusun dan Ibu PKK serta Warga Desa Tanjung Seteko, Kecamatan Indralaya, Kabupaten Ogan Ilir, Provinsi Sumatera Selatan.

Kesuksesan dan kelancaran kegiatan penyuluhan hukum ini disebabkan oleh beberapa faktor seperti memahami kondisi kultur/budaya beserta dan kemampuan berkomunikasi dengan menggunakan bahasa yang sederhana sehingga dapat dipahami dengan mudah oleh peserta atas materi yang disampaikan tim penyuluh. Menurut jenis dan sifat pelaksanaan penyuluhan hukum tersebut, Terdapat beberapa metode dalam merealisasikan kegiatan penyuluhan hukum yang dilaksanakan di Desa Tanjung Seteko, Kecamatan Indralaya, Kabupaten Ogan Ilir, Provinsi Sumatera Selatan tersebut, antara lain ialah:

a. Ceramah

Ceramah yang dimaksudkan disini adalah penyampaian materi dilaksanakan dengan proses atau cara tatap muka dari tim penyuluh $\mathrm{FH}$ Unsri dengan dan warga desa setempat, dengan tujuan untuk memberikan informasi yang komprehensif mengenai persoalan KDRT dan proses penyelesaian sengketa melalui luar pengadilan (non-litigasi).

b. Diskusi Dan Sharing Ilmu

Setelah dilaksanakan kegiatan ceramah, kemudian diadakan juga kegiatan tanya jawab antara tim penyuluh FH Unsri dengan warga Desa Tanjung Seteko, Kecamatan

\begin{abstract}
Indralaya, Kabupaten Ogan Ilir, Provinsi Sumatera Selatan. Kemudian warga akan diberikan kuisioner untuk diisi dan tim penyuluh akan melihat bagaimana cara pandang mereka untuk memahami materi yang belum jelas dalam ceramah.
\end{abstract}

Tercapai atau tidaknya tujuan dari kegiatan ini dapat diketahui dengan melakukan tes umpan balik melalui metode sesi diskusi dua arah. Maksudnya ialah tim penyuluh menanyakan kembali kepada peserta atas materi yang sudah disampaikan. Peserta apabila memahami $75 \%$ dari materi yang disampaikan. Maka Warga desa Desa Tanjung Seteko, Kecamatan Indralaya, Kabupaten Ogan Ilir, Provinsi Sumatera Selatan dianggap telah berhasil memahami persoalan Penyelesaian Hukum Kekerasan Dalam Rumah Tangga Yang Dilakukan Suami Terhadap Istri Di Luar Pengadilan. Sebaliknya, Jika ternyata hasilnya kurang dari $75 \%$ maka akan disampaikan secara spesifik oleh tim penyuluh supaya warga benar benar memahami secara komprehensif materi tersebut.

\section{HASIL DAN PEMBAHASAN}

Pada mulanya persiapan yang dilakukan ini dengan mempersiapkan semua bahan - bahan yang berkaitan dengan kegiatan, yaitu pegumpulan literatur dengan cara studi kepustakaan mulai dari buku - buku, artikel di jurnal ilmiah, situs website resmi miliki pemerintah, media massa baik media cetak maupun media online yang mempunyai korelasi dengan topik penyuluhan yang disampaikan oleh tim. Meskipun dilaksanakan dalam situasi pandemi Covid - 19, kegiatan pengabdian masyarakat dapat dilaksanakan seperti pada umumnya dengan tetap memerhatikan protokol kesehatan, salah satu contoh seperti mencuci tangan. Adapun kegiatan pengabdian tersebut diadakan pada : Hari/Tanggal Sabtu, 11 September 2021, Pukul 09.00 WIB sampai dengan Pukul 12.00 WIB. Adapun peserta kegiatan ialah kepala desa, aparat desa, kepala dusun dan Ibu PKK serta Warga Desa Tanjung Seteko, Kecamatan Indralaya, Kabupaten Ogan Ilir, Provinsi Sumatera Selatan. Kegiatan penyuluhan ini diikuti oleh 50 Orang Peserta yang berasal dari aparat desa, kepala dusun dan Ibu PKK serta Warga Desa Tanjung Seteko. Penyuluhan yang dilaksanakan dengan terjun langsung di lokasi pengabdian tersebut, 
menggunakan metode pemaparan materi dan sesi diskusi tanya jawab yang melibatkan 50 peserta mengamati secara komprehensif setiap paparan yang disampaikan narasumber dan berperan aktif dalam kegiataan penyuluhan tersebut.

Kekerasan Dalam Rumah Tangga atau biasa dikenal oleh masyarakat umum yaitu KDRT, merupakan fenomena yang masih dianggap biasa bahkan dianggap suatu tindakan yang normal dialami dalam kehidupan rumah tangga antara suami dan istri. Paradigma yang menganggap KDRT merupakan kebiasaan yang ada di tengah kalangan masyarakat, harus segera dihilangkan [10]. Hal ini mengingat KDRT tersebut dapat memberikan dampak psikis, sosial di masyarakat bahkan dampak fisik bagi korbannya sangat dimungkinkan dapat terjadi.[11] Adapun mayoritas korban dalam KDRT ini ialah pihak perempuan atau si istri. Terkait persoalan tersebut, maka ditemukan masalah - masalah yang ditemukan pada saat kegiatan penyuluhan tersebut, antara lain:

a. Masih kurangnya pemahaman mengenai terminologi maupun bahaya yang ditimbulkan dari tindakan KDRT tersebut bagi pihak pelaku maupun korban.

b. Pemahaman pihak suami maupun istri mengenai pentingnya penanaman nilai moral, pendidikan dan agama dalam membangun ikatan keluarga masih begitu kurang. Bahkan pihak orang tua yaitu suami (sebagai pelaku) dan istri (sebagai korban), tidak mengetahui bahwa tindakan KDRT yang mereka alami dampak memberikan dampak negatif bagi anak - anaknya terutama dalam aspek psikisnya

c. Eksistensi UU Nomor 23 tahun 2004 tentang Penghapusan Kekerasan dalam Rumah Tangga (UU PKDRT) sebagai landasan yuridis normatif yang memberi perlindungan hukum bagi korban dalam hal ini perempuan, masih belum optimal dalam aspek implementasinya.

d. Para warga desa tanjung seteko masih bingung dalam melaksanakan langkah - langkah hukum dalam menangani kasus Kekerasan Dalam Rumah Tangga (KDRT), baik langkah hukum yang bersifat preventif maupun represif. Terutama bagi warga yang mengetahui jika ada warga tetangganya mengalami kasus Kekerasan Dalam Rumah Tangga (KDRT), maka sesuai Pasal 15 UU No. 23 tahun 2004 tentang Penghapusan Kekerasan dalam Rumah Tangga, warga yang mengetahui tersebut dapat melakukan upaya untuk mencegah bahkan melaporkan kasus tersebut.

e. Kurangnya pemahaman mengenai jenis Kekerasan Dalam Rumah Tangga (KDRT), yang menganggap bahwa hanya kekerasan fisik saja, padahal adajenis kekerasan lainnya yaitu kekerasan psikis, kekerasan seksual dan penelantaran rumah tangga

f. Optimalisasi penyelesaian kasus KDRT di jalur nonlitigasi, seperti mediasi, sistem kekeluargaan, dan semacamnya, masih belum dipahami secara optimal.

Berdasarkan permasalahan yang dipaparkan di atas, Tim penyuluhan Fakultas Hukum Universitas Sriwijaya melakukan Penyuluhan Hukum Penyelesaian Hukum Kekerasan Dalam Rumah Tangga Yang Dilakukan Suami Terhadap Istri Di Luar Pengadilan Di Desa Tanjung Seteko, Kecamatan Indralaya, Kabupaten Ogan Ilir, Provinsi Sumatera Selatan dengan memberikan pengetahuan melalui paparan (presentasi), diskusi, maupun tanya jawab terkait

a. Terminologi maupun bahaya yang ditimbulkan dari tindakan Kekerasan Dalam Rumah Tangga (KDRT) tersebut bagi pihak pelaku maupun korban.

b. Penjelasan mengenai jenis - jenis Kekerasan Dalam Rumah Tangga (KDRT), yaitu Kekerasan Fisik, Kekerasan Psikis, Kekerasan Seksual dan Penelantaran Rumah Tangga.

c. Perlindungan hukum bagi korban dalam hal ini permpuan yang mengalami tindakan perundungan

d. Upaya hukum yang dapat dilakukan mulai dari upaya preventif hingga represif (penerapan sanksi) yang sudah diatur dalam regulasi, yaitu UU No. 23 tahun 2004 tentang Penghapusan Kekerasan dalam Rumah Tangga 
e. Peran serta pihak warga desa tanjung seteko dalam menanggulangi kasus tindakan Kekerasan Dalam Rumah Tangga (KDRT) yang terjadi di sekitarnya.

f. Optimalisasi penyelesaian hukum di luar pengadilan dalam kasus Kekerasan Dalam Rumah Tangga (KDRT) dengan cara seperti contoh negoisasi, mediasi, dan semacamnya dengan melibatkan peran aparatur desa.

Respon yang diperlihatkan peserta terkait topik kegiatan penyuluhan hukum ini begitu baik. Peran aktif peserta untuk terlibat dalam kegiatan penyuluhan hukum tersebut ditunjukan dengan adanya diskusi dua arah dan sesi tanya jawab yang dilaksanakan selama proses kegiatan berlangsung. Pada sesi tanya jawab, para peserta diberi kesempatan dua pertanyaan untuk diajukan kepada tim penyuluh, dan faktanya pada setiap sesi terdapat lebih dari dua orang yang bertanya kepada tim penyuluh. Pertanyaan yang diajukan para peserta, mayoritas berdasarkan pengalaman pengalaman dari para warga Desa Tanjung Seteko terkait kasus KDRT yang menimpa warganya dan proses penyelesaian hukum yang dilakukan untuk mengatasi persoalan rumah tangga tersebut.

Respon yang sangat baik juga dapat terlihat ketika tim penyuluh menyampaikan sesi umpan balik, dengan mengajukan 4 (empat) pertanyaan yang diambil dari materi mengenai Penyelesaian Hukum secara Nonlitigasi Kekerasan Dalam Rumah Tangga Yang Dilakukan Suami Terhadap Istri, yang disampaikan ketika proses penyuluhan hukum berlangsung secara acak kepada peserta penyuluhan. Empat pertanyaan yang disampaikan tim penyuluh tersebut, berhasil dijawab dengan baik oleh peserta penyuluhan.

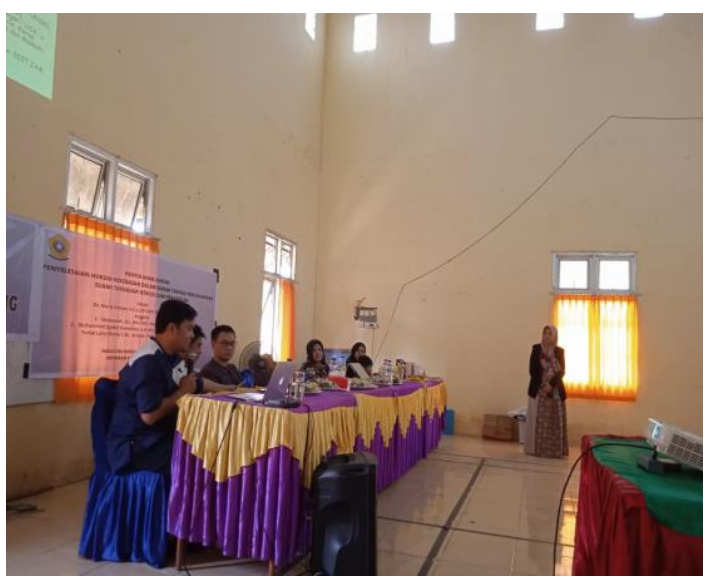

Foto: Ketua Tim Penyuluh Dosen FH Unsri Dr. Meria Utama sedanga menyampaikan materi kepada warga di balai desa Tanjung Seteko, Kecamatan Indralaya, Kabupaten
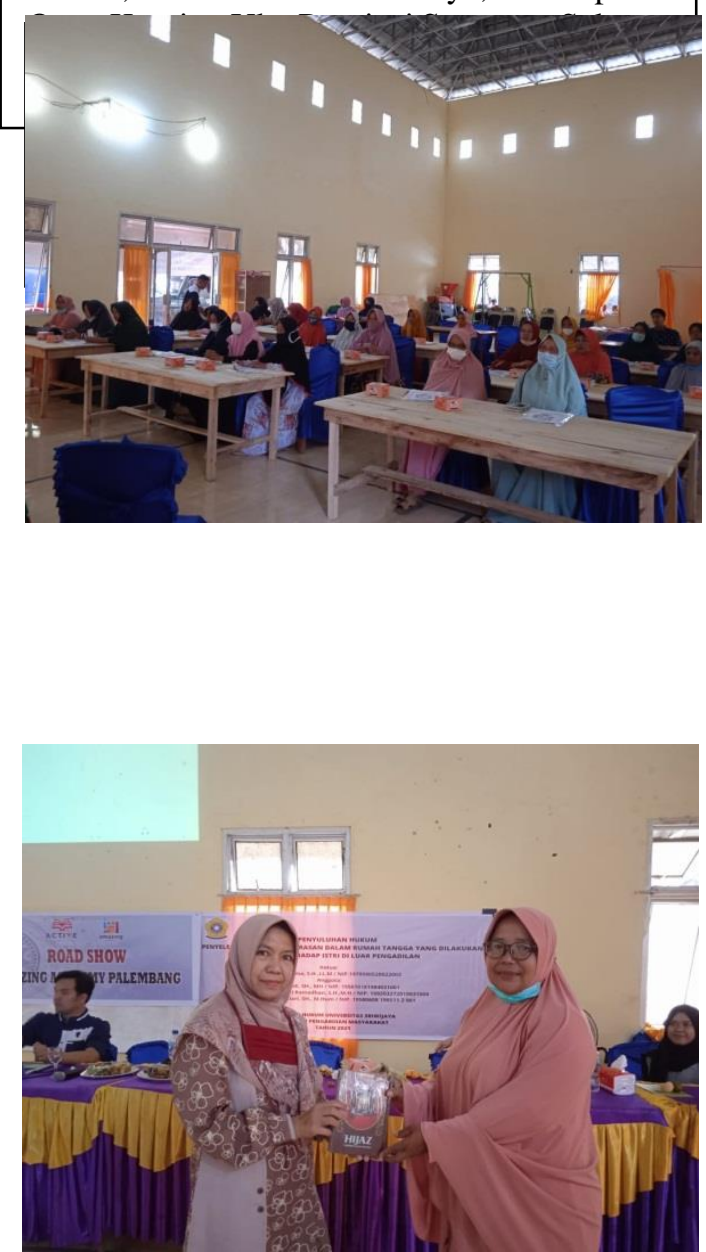

Foto: Pemberian kenang - kenangan dari FH Unsri kepada Desa Tanjung Seteko yang diwakili oleh Ibu PKK

point yang kemudian ditampilkan di hadapan seluruh peserta penyuluhan. Tim penyuluh sudah berkoordinasi dengan kepala desa tanjung seteko sekitar 14 (empat belas hari) sebelum hari - H pelaksanaan kegiatan penyuluhan. Adapun koordinasi yang dilaksanakan ialah memberi informasi tentang maksud kedatangan tim penyuluh hukum FH Unsri ke desa tanjung seteko yaitu dalam rangka Penyuluhan Hukum Penyelesaian Hukum secara Nonlitigasi Kekerasan Dalam Rumah Tangga Yang Dilakukan Suami Terhadap Istri. Tidak ditemukan kendala atau hambatan dalam memanfaatkan dalam melaksanakan kegiatan penyuluhan tersebut mulai dari persiapan 
administrasi hingga pelaksanaan kegiatan. Mengingat warga desa tanjung seteko sudah terbiasa kedatangan tamu dari perguruan tinggi negeri maupun swasta terkait kegiatan penyuluhan, Kuliah Kerja Nyata $(\mathrm{KKN})$, dan seterusnya. Jadi, para warga sudah memahami maksud kedatangan dan mengerti seputar kegiatan penyuluhan tersebut.

$$
\text { Tahapan selanjutnya ialah }
$$
menyampaikan materi kepada warga Desa Tanjung Seteko, Kecamatan Indralaya, Kabupaten Ogan Ilir, Provinsi Sumatera Selatan antara lain adalah dampak negatif dari KDRT, cara mencegah atau menghindari KDRT, Bentuk - Bentuk KDRT sebagaimana diatur dalam UU PKDRT. Pentingnya memberikan pemahaman kepada kaum perempuan yang dimana selalu menjadi korban dalam KDRT, bahwa UU PKDRT secara komprehensif memberikan perlindungan hukum bagi kaum perempuan, pentingnya memberikan pemahaman kepada kedua orang tua untuk mencegah timbulnya KDRT mengingat tindakan tersebut akan berdampak kepada hancurnya psikologis bagi si anak [2], sanksi hukum yang dapat dikenakan bagi pelaku KDRT sebagaimana diatur dalam UU PKDRT, proses penyelesaian hukum di luar pengadilan terhadap kasus kekerasan dalam rumah tangga dengan melibatkan aparat desa sebagai mediatornya.

Tahapan selanjutnya ialah diskusi dan tanya jawab mengenai tindakan KDRT, baik dari sisi peraturan perundang - undangan maupun dari peran serta yang dapat dilakukan oleh warga desa tanjung seteko. Tahapan ini merupakan tahapan evaluasi yaitu untuk mengetahui perubahan sikap dan peningkatan pengetahuan warga terhadap aturan hukum dan perilaku yang berkaitan dengan kasus KDRT.

Dari serangkaian kegiatan penyuluhan di atas, tim penyuluh dapat melihat bahwa para warga belum mengetahui sepenuhnya mengenai eksistensi UU PKDRT, yang dimana memberi perlindungan kepada perempuan sebagai korban. Maka dari itu, materi penyuluhan hukum mengenai KDRT sangat penting untuk disampaikan kepada warga desa tanjung seteko, hal ini supaya warga tahu jika ada tetangga atau orang di sekitarnya mengalami kekerasan dalam rumah tangga, maka sebagaimana amanah dari undang - undang, warga tersebut berhak terlibat untuk menanganinya. Hasilnya para peserta sudah memulai memahami tentang eksistensi UU PKDRT tersebut.

Para warga desa tanjung seteko, khususnya para aparat desa maupun kepala desa disana. Berdasarkan pengakuan mereka, bahwa para aparat desa berperan aktif dalam menyelesaiakan persoalan kasus Kekerasan dalam Rumah Tangga yang dialami oleh warganya. Hal yang membuat para aparat desa berperan aktif dalam menyelesaikan kasus tersebut, mengingat mayoritas warga berpersepsi bahwa kasus hukum yang diselesaikan melalui jalur litigasi seperti melapor kepolisian (meskipun ini salah satu poin penting yang diatur dalam UU PKDRT), membutuhkan waktu yang lama dan bertele - tele. Berdasarkan pernyataan yang disampaikan warga tersebut, maka tim penyuluh dapat memberikan konklusi bahwa warga tanjung seteko memahami proses penyelesaian sengketa di luar pengadilan (nonlitigasi) lebih efisien dibandingkan melalui pengadilan (litigasi).

\section{KESIMPULAN}

Berdasarkan dari penyuluhan hukum yang dilakukan terhadap warga Desa Tanjung Seteko, Kecamatan Indralaya, Kabupaten Ogan Ilir, Provinsi Sumatera Selatan, maka dapat di ambil beberapa kesimpulan sebagai berikut:

1. Kekerasan Dalam Rumah Tangga (KDRT) merupakan tindakan yang sangat merugikan bagi bagi si pelaku maupun korban. Pelaku KDRT ini biasanya adalah pihak suami sedangkan untuk yang menjadi korban adalah pihak istri. Fenomena ini seringkali terjadi dikarenakan masih ada disorientasi bahwa pihak istri sudah seharus ada dibawah kendali pihak suami. Prinsip hubungan paternalistik antara pihak istri dan suami inilah yang menyebabkan tindakan KDRT tidak dapat dihindarkan. Selanjutnya, masih banyak warga yang belum memamahi secara komprehensif mengenai eksistensi dari UU No. 23 tahun 2004 tentang Penghapusan Kekerasan dalam Rumah Tangga, yang dimana fokus utamanya memberikan perlindungan hukum bagi kaum perempuan atau istri. Di samping itu, di dalam undang undang tersebut juga memberikan definisi secara utuh bahwa kekerasan dalam rumah tangga tidak hanya kekerasan fisik saja, tetapi juga ada kekerasan psikis, seksual dan penelantaran rumah tangga.

2. Perlindungan terhadap korban dari tindakan kekerasan dalam rumah tangga ada dua cara yakni: Pertama, Pencegahan terjadinya kekerasan dalam rumah tangga . Kedua, Perlindungan 
terhadap korban kekerasan dalam rumah tangga. Apabila dicermati maka perlindungan hukum di atur dalam penjelasan pasal-pasal mengenai sanksi yang sudah diatur mulai dari Pasal 44 sampai dengan Pasal 55 UU No. 23 tahun 2004 tentang Penghapusan Kekerasan dalam Rumah Tangga. Namun, demi mengupayakan keutuhan keluarga dan demi kebahagiaan anak maka setiap pesoalan rumah tangga sekalipun terdapan unsur kekerasan dalam rumah tangga, sebaiknya diselesaikan melalui di luar jalur pengadilan dibandingkan melalui jalur pengadilan. Hal ini sebagaimana dilakukan oleh aparat desa tanjung seteko yang berperan aktif dalam menyelesaikan kasus tersebut, mengingat mayoritas warga berpersepsi bahwa kasus hukum yang diselesaikan melalui jalur litigasi seperti melapor kepolisian (meskipun ini salah satu poin penting yang diatur dalam UU No. 23 tahun 2004 tentang Penghapusan Kekerasan dalam Rumah Tangga), membutuhkan waktu yang lama dan bertele - tele. Berdasarkan pernyataan yang disampaikan warga tersebut, maka tim penyuluh dapat memberikan konklusi bahwa warga desa tanjung seteko memahami proses penyelesaian sengketa di luar pengadilan (nonlitigasi) lebih efisien dibandingkan melalui pengadilan (litigasi).

\section{UCAPAN TERIMAKASIH}

Penulis mengucapkan terimakasih kepada LPPM Universitas Sriwijaya yang turut serta dalam mengakomodir pelaksanaan kegiatan pengabdian ini. Terimakasih penulis sampaikan kepada Tim Pengelola Jurnal Atma Inovasia (JAI) yang mengurus dan memberikan kesempatan penulis untuk publish artikel jurnal ini. Semoga dapat memberikan manfaat bagi kalangan civitas Universitas Sriwijaya dan Universitas Atmajaya serta bagi semua pembaca.

\section{DAFTAR PUSTAKA}

[1] S. Hadi, "PENERAPAN ASAS KEADILAN TERHADAP TINDAK PIDANA KEKERASAN DALAM RUMAH TANGGA BERDASARKAN UNDANG UNDANG NOMOR 23

$\begin{array}{lr}\text { TAHUN } 2004 & \text { TENTANG } \\ \text { PENGHAPUSAN } & \text { KEKERASAN } \\ \text { DALAM RUMAH TANGGA," } & \text { Aktual. } \\ \text { (Jurnal Hukum), 2020, } & \text { doi: } \\ \text { 10.29313/aktualita.v0i0.5690. } & \end{array}$

[2] Badriyah Khaleed, Penyelesaian Hukum Kekerasan Dalam Rumah Tangga $(K D R T)$. Yogyakarta: Medpress Digital, 2015.

[3] D. Lestari, "KEKERASAN DALAM RUMAH TANGGA TERHADAP PEREMPUAN," J. Huk. Pembang., vol. 35, no. 3, 2017, doi: 10.21143/jhp.vol35.no3.1516.

[4] Ridwan, Kekerasan Berbasis Gender (Rekonstruksi Teologis, Yuridis, dan Sosiologis). Purwokerto: Pusat Studi Gender (PSG) STAIN Purwokerto, 2006.

[5] UNDANG-UNDANG REPUBLIK INDONESIA NOMOR 23 TAHUN 2004 TENTANG PENGHAPUSAN KEKERASAN DALAM RUMAH TANGGA. Indonesia.

[6] Ponny Retno Astuti, 3 Cara Meredam Bullying, I. Jakarta: PT. Gramedia Widasarana Indonesia, 2008.

[7] Saptosih Ismiati, Kekerasan Dalam Rumah Tangga (KDRT) dan Hak Asasi Manusia (HAM), I. Yogyakarta: Deepublish, 2020.

[8] Lely Sestyawati Kurniawan, Refleksi Diri Para Pelaku dan Korban Kekerasan Dalam Rumah Tangga: Apakah Jiwaku Sehat? Yogyakarta: Andi Offset, 2015.

[9] S. S. Dahwadin, Muhamad Dani Somantri, Enceng Iip Syaripudin, Perceraian Dalam Sistem Hukum Indonesia, I. Wonosobo: Mangkubumi, 2018.

[10] D. Sukardi et al., "Kajian Kekerasan Rumah Tangga Dalam Perspektif Hukum Islam Dan Hukum Positif," Didi Sukardi Kaji. Kekerasan Rumah Tangga Mahkamah, 2015.

[11] D. Karya, "TINDAK PIDANA KEKERASAN DALAM RUMAH TANGGA YANG DILAKUKAN SUAMI TERHADAP ISTRI (Studi Kasus Di Pengadilan Negeri Gresik)," DiH J. Ilmu Huk., vol. 9, no. 17, 2013, doi: 10.30996/dih.v9i17.248.

\section{Penulis}



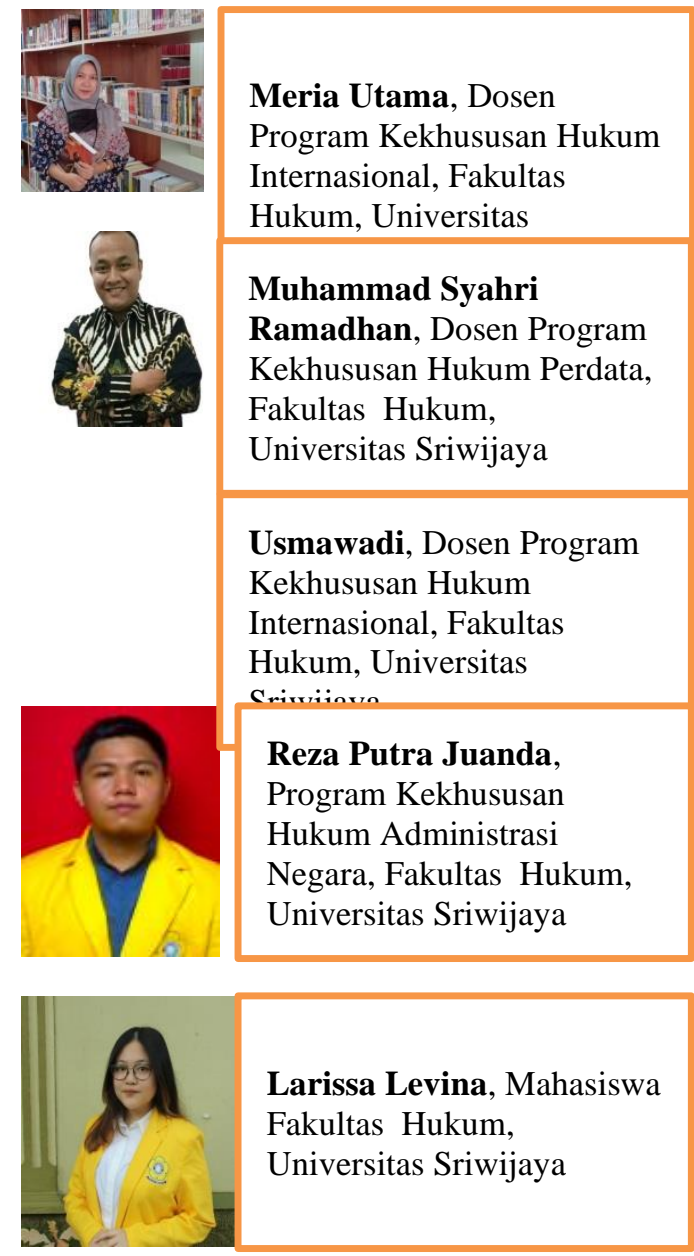

Muhammad Rezky Bagus
Rekso, Program
Kekhususan Hukum Pidana,
Fakultas Hukum,
Universitas Sriwijaya
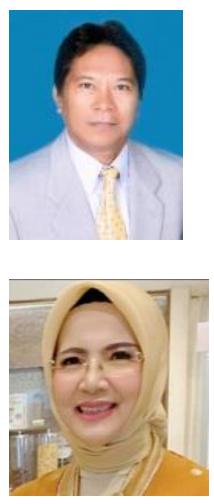

Yunial Laily Mutiari,

Dosen Program Kekhususan

Hukum Perdata, Fakultas

Hukum, Universitas

Sriwijaya 